\title{
The analysis of agritourism accommodation indicators for areas located in the vicinity of national parks
}

\author{
KONRAD PODAWCA, AGATA PAWŁAT-ZAWRZYKRAJ \\ Faculty of Civil and Environmental Engineering, Warsaw University of Life Sciences - SGGW
}

\begin{abstract}
The analysis of agritourism accommodation indicators for areas located in the vicinity of national parks. Increasing tourism development makes it an important factor in generating economic growth and employment in the European Union. Due to high environmental attractiveness of many regions, this sector of economy plays an important role in Poland as well. The essential principle of functioning of tourism is to provide adequate accommodation. It seems that less intensive and less aggressive accommodation, based on existing housing stock, would be most appropriate in areas with high natural values. The article presents research on agritourist accommodation in 23 areas located in the vicinity of national parks. Obtained results allowed to assess an extent to which agritourism is a popular form of additional activity for inhabitants of such areas, which is also a form of activation of local communities. The analysis was done using a multivariate method. Indicators of intensity of agritourist accommodation and agritourist accommodation places, as well as their surface density were calculated. Obtained results enabled the authors to divide the analysed areas into 4 types in terms of intensity of agritourist accommodation related to other sorts of accommodation and the density of agritourist accommodation. It is generally stated that the agritourist accommodation neither prevail nor develop on a level comparable to other forms of accommodation on the analyzed areas. In this respect, it can prove that location of the area in the vicinity of a national park is not a sufficient guarantee of intensive agritourism development.
\end{abstract}

Key words: agritourism, agritourist accommodation, nature protection areas, land management

\section{INTRODUCTION}

Intensive development of various forms of recreation, mobility of people and desire to travel and explore, cause tourism to play an important role in generating economic growth and employment in the European Union. This field has become a very important type of activity also for the Polish economy.

In Poland, agritourism is a phenomenon of the 1990s, although its bases go back to much older times. It was from this period that the issue of agritourism, its conditions, development opportunities and threats were investigated in terms of the rural farm (Podawca and Dąbkowski 2000), in the socio-economic context (Jalnik 2009, Sikora 2012, Brelik 2014) or spatial approach (Drzewiecki 1992, Wiatrak 1996, Podawca 2006).

Agrotourism issues are constantly updated. They are not only the subject of scientific studies (e.g. within the framework of the National Scientific Conference on Rural Tourism: Science-Education-Practice in June 2016 in Poznań), but they are also included in government 
programs, such as Rural Development Programme for 2014-2020 (MRiRW 2017), through bonuses for setting up non-agricultural activities, including tourism.

At the same time, apart from the positive aspects of the tourism development, it should be noted that the current, dynamic and not always controlled development of tourist infrastructure and the related increase of traffic, as well as the impact on spatial development, can be considered as one of the major and significant factors of human pressure on the natural environment (Myga-Piątek and Jankowski 2009).

In the literature (Jalinik 2010, Sokół 2012), one can find opinions that Poland is a very diversified country in terms of the spatial distribution of agritourism farms. The precursors of agritourism development were, above all, the northern and southern voivodships, leading in statistics concerning the number of agritourism farms. The potential reasons for uneven development of agritourism in different regions are, among others: high natural diversification of the country, economic inequality of the regions, historical events, geographic location, holiday traditions. Spatial distribution of this form of non-agricultural activity was discussed by several authors (Nowak and Korab 2012, Bednarczyk-Szczepańska and Bański 2014, Przezbórska-Skobieraj and Sobotka 2016), who pointed out relationship between the location of agritourism farms and the natural values of the areas. Many of these facilities are located in the vicinity of national parks, landscape parks and other areas covered by nature conservation (Płazińska 2016).
The research carried out in national parks concerned mainly the following issues: forms of tourism and the incoming tourism volume (Cieszewska 2009, Kobyłka and Kulawczuk 2014), evaluation of the operation of agritourism farms (Ciepiela and Kur-Kowalska 2014) or natural and landscape potential of the parks (Prukop and Herbert 2014). However, they did not evaluate the intensity of agritourism development in relation to other types of accommodation, nor did they compare their density in areas of very high natural value.

Many authors (Podawca 2004, Basiński et al. 2012, Sokół 2012) claim that the national parks and landscape parks are the ideal areas for agritourism development, and that the offer of agritourism farms is so attractive to tourists, that it creates not only great opportunities for the improvement of the economic situation of these facilities, but also brings benefits to the protected areas.

It is assumed that less intensive and less aggressive accommodation based on existing building stock would be most appropriate in areas of great natural value. The agritourist accommodation is defined as a kind of tourist accommodation, which consists of rooms, houses and adapted farm buildings (agricultural, breeding, horticulture or fishing), owned by farmers, rented to tourists for a fee (http://form.stat.gov.pl/formularze/2014/passive/KT-1.pdf).

\section{MATERIAL AND METHODS}

On the basis of the literature review, it can be stated that areas located in the vicinity of national parks are characterized by high correlation between 
natural and tourism aspects. The survey covered 23 areas composed of municipalities, which have been fully or partially granted natural protection as a national park. This is a specific set of administrative units, where the tourism management plays a key role in spatial management.

The cognitive aim of the paper is to present the diversity of areas located in the direct vicinity of national parks in Poland, in terms of the presence of agritourist accommodation. The most important aspect of the study concerns the broadly understood tourism development, shown by a comparative analysis of parameters, determining equipment in facilities and accommodation places, with particular regard to agritourism. The analysis is supposed to show not only the quantitative status but also the spatial distribution of the agritourist accommodation in the areas where the issues of natural conditions and environmental protection are the key factors. Showing the quantitative aspects of accommodation development and above all, the unification of the studied features by the proposed indicators, allows to establish typology of the analyzed areas.

The method used in the research is the comparative analysis using indicators, understood as numbers expressing the level of a given phenomenon or feature, presented in absolute or relative terms (Zielińska 2006). The multivariate characteristic is often used for scientific purposes and its results consist of a typological set of certain areas representing common features.

The starting point was to determine a set of relevant diagnostic features and their representative measurements. It was recognized that the number of accommodation facilities, including agritourist ones and the number of places (beds), including these in agritourism farms, would illustrate the state of accommodation. The designated features are related to each other or to the agricultural built-up area, making it possible to compare the analyzed areas regardless of their size.

The study methods used, can be divided into two groups:

- statistical method of data collection, based on information provided by the Local Data Bank (BDL) for 2016, in the field of tourism;

- data-processing methods, including mainly the analysis and comparison methods.

In order to assess the importance of agritourist accommodation in the development of accommodation facilities, the focus has been placed on use of objective indicators illustrating two basic characteristics: the number of accommodation facilities and the number of accommodation places (beds). The formulas presented below have been developed by the authors.

In case of the first feature (the number of accommodation facilities), the following formula has been used:

$$
I_{i a t}=\left(N_{a t} / N_{a f}\right) \cdot 100 \%
$$

where:

$I_{i a t}$ - indicator of the intensity of agritourist accommodation (\%);

$N_{a t}$ - number of agritourist accommodation;

$N_{a f}$ - total number of accommodation facilities. 
For the second feature, i.e. the number of accommodation places, the indicator is calculated by this formula:

$I_{\text {iatp }}=\left(N_{\text {atp }} / N_{a p}\right) \cdot 100 \%$

where:

$I_{\text {iatp }}$ - indicator of the intensity of agritourist accommodation places (\%);

$N_{a t p}$ - number of agritourist accommodation places;

$N_{a p}$ - total number of accommodation places.

The indicators presented above, enabled us to observe the share of agritourist accommodation facilities within the general number of accommodation. However, the picture given by the obtained indicators seems to be incomplete for the comparison of the analyzed areas, because of lack of reference to the size of the area on which these facilities can be located. Therefore, it was decided to include two additional spatial indicators referring only to the agritourism:

- the indicator of areal density of agritourist accommodation, expressed by the formula:

$I_{d a t}=\left(N_{a t} / L_{a b}\right)$

where:

$I_{\text {dat }}$ - indicator of the areal density of agritourist accommodation (\%);

$N_{a t}$ - number of agritourist accommodation;

$L_{a b}$ - agricultural built-up area $\left(\mathrm{km}^{2}\right)$.
- the indicator of areal density of agritourist accommodation places, calculated by the formula:

$I_{\text {datp }}=\left(N_{a t p} / L_{a b}\right)$

where:

$I_{\text {datp }}$ - indicator of the density of agritourist accommodation places (\%);

$N_{a t p}$ - number of agritourist accommodation places;

$L_{a b}$ - agricultural built-up area $\left(\mathrm{km}^{2}\right)$.

\section{RESULTS}

The analyzed areas (23) constitute a set of areas ranging from $196.14 \mathrm{~km}^{2}$, in case of the areas located in the vicinity of the Babia Góra NP, to $3,268.4 \mathrm{~km}^{2}$ in case of the Biebrza NP. The size of the studied units is between 500 and $1,000 \mathrm{~km}^{2}$ and is considered quite large. More important however, is the size of agricultural builtup area, where agritourist accommodation may be developed. The lowest share of such area in land-use structure is observed in case of Babia Góra NP and the highest in Biebrza NP. The size of the analyzed units is not always proportional to the size of agricultural built-up area. The largest disproportion occurred in the vicinity of Ojców NP, Świętokrzyski NP, Roztocze NP, Bieszczady NP and Słowiński NP.

In most analyzed units, the existence of agritourist accommodation is relatively limited. The situation is better only in areas located in the vicinity of Tatra NP, Świętokrzyski NP, Pieniny NP and Białowieża NP, which is reflected in the analyzed indicators. Detailed data is presented in Table 1. 


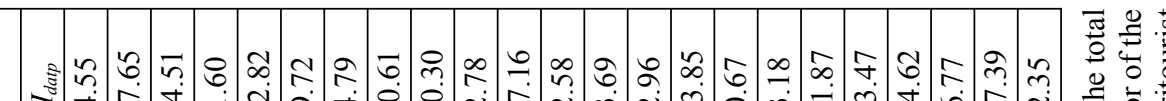

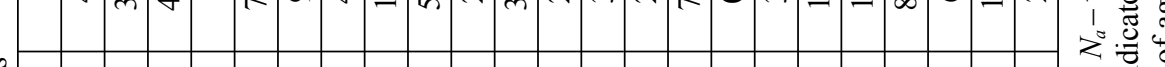

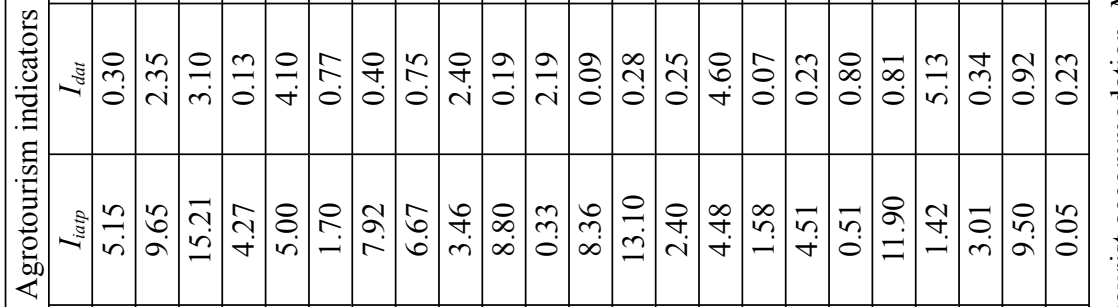

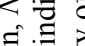

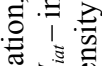

过

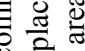

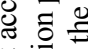

至

总穿

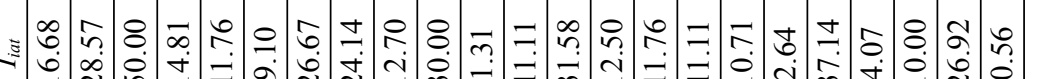
पै

尝

$\stackrel{8}{ \pm}$

$\stackrel{\Xi}{\Xi}$

可

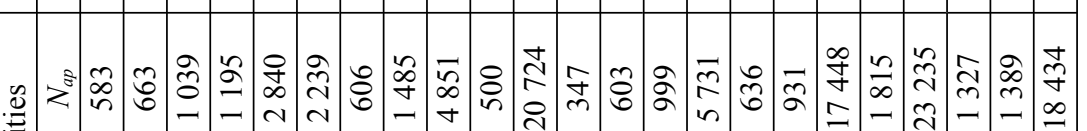

,

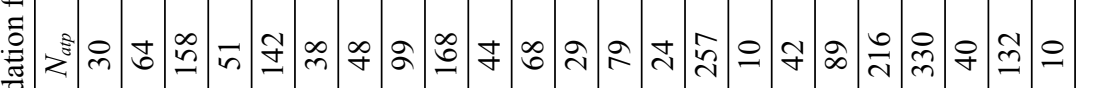

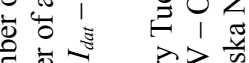

군 $\frac{\pi}{\pi}$

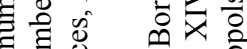

宗产

$>3$

นึ

흘

i

艺

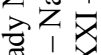

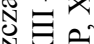

就

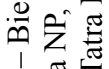

రㄹ.

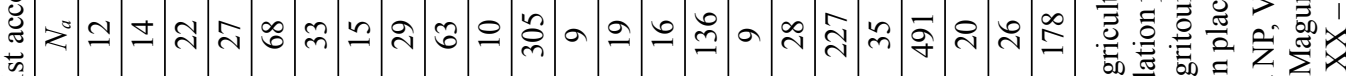

$\stackrel{n}{\Xi}$

ส

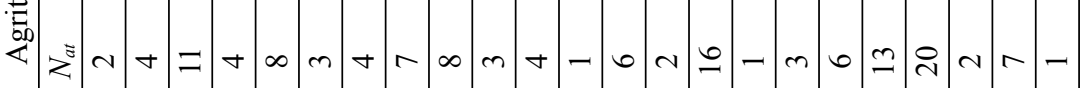

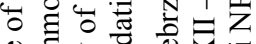

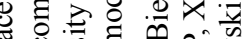
ठํ.

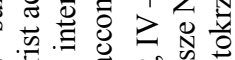
$1 \cdot 0$ :

สี ن

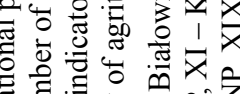

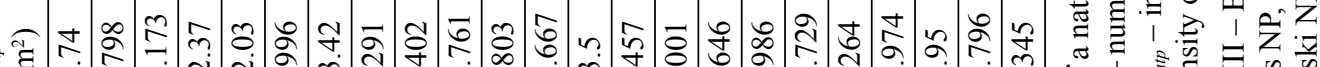

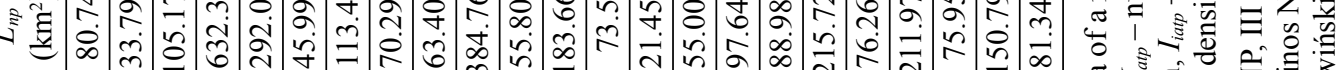

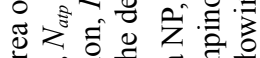

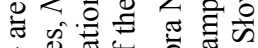

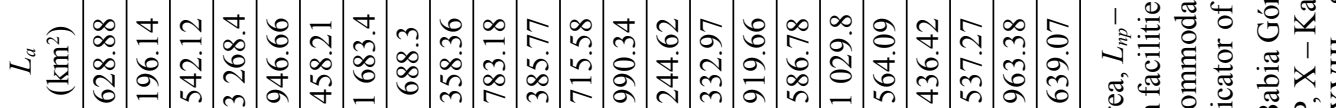

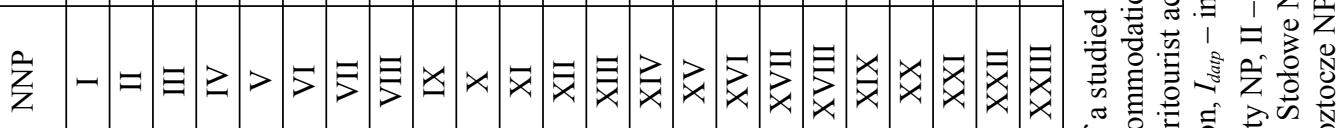
$\stackrel{0}{ \pm}$

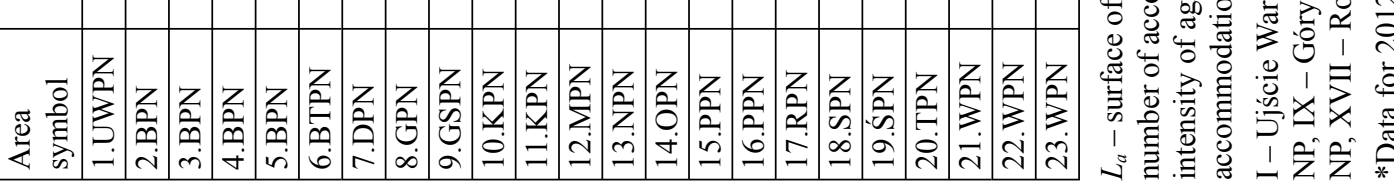


The analysis of data presented in Table 1 enabled to indicate 4 types of areas. In case of intensity of agritourist accommodation, the division was made assuming that, from the point of view of sustainable environment and economic development, it is considered desirable that at least $50 \%$ of the tourism resources should constitute agritourist accommodation. The following types of areas were established:

- $0-15 \%$ - the areas with low level of intensity of the agritourist accommodation - Type I;

- $<15-30 \%$ - the areas with medium level of intensity of the agritourist accommodation - Type II;

- $<30-50 \%$ - the areas with high level of intensity of the agritourist accommodation - Type III;

- $\geq 50 \%$ - the areas with very high level of intensity of the agritourist accommodation - Type IV.

The spatial distribution of the areas classified to these types is presented in the Figure 1.

In case of intensity of agritourism accommodation in relations to all accommodation places, the thresholds for individual intervals were reduced. This is due to the fact that a single agritourism farm can offer significantly less accommodation places compared to a guest house or a hotel. In this case the following types of areas were determined:

- $0-5 \%$ - the area with low share of agritourist accommodation places - Type I;

- 5-10\% - the area with medium share of agritourist accommodation places - Type II;
- $10-15 \%$ - the area with high share of agritourist accommodation places - Type III;

- $\geq 15 \%$ - the area with very high share of agritourist accommodation places - Type IV.

Spatial distribution of areas assigned to the above types is presented in Figure 1.

In the analysis concerning density of agritourist accommodation, the resulting division takes into account the fact, that a farmer providing agritourism services can rent up to 5 rooms at the same time (what is equal to $10-15$ tourists) without tax consequences. As a result, the following types have been developed:

- the areas with low density of the agritourist accommodation $(<0.5$ agritourist accommodation or 10 places in an accommodation for $1 \mathrm{~km}^{2}$ of the agricultural built-up area) - Type I;

- the areas with medium density of the agritourist accommodation (0.5-1 agritourist accommodation or 10-25 places in an accommodation for $1 \mathrm{~km}^{2}$ of the agricultural built-up area) - Type II;

- the areas with high density of the agritourist accommodation (1-3 agritourist accommodation or 26-40 places in an accommodation for $1 \mathrm{~km}^{2}$ of the agricultural built-up area) Type III;

- the areas with very high density of the agritourist accommodation ( $>3$ agritourist accommodation or $>40$ places in an accommodation for $1 \mathrm{~km}^{2}$ of the agricultural built-up area) Type IV - Figure 2. 


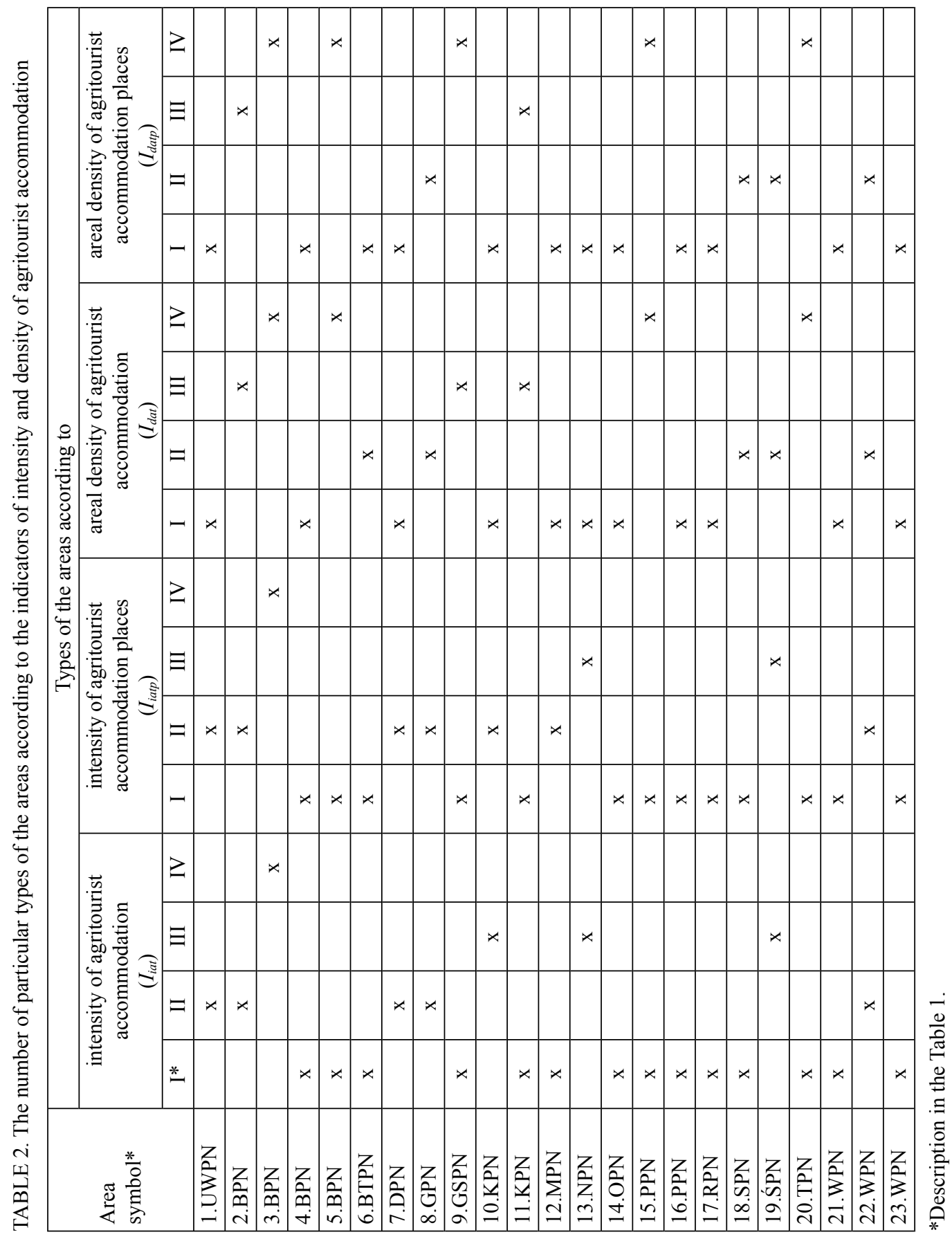



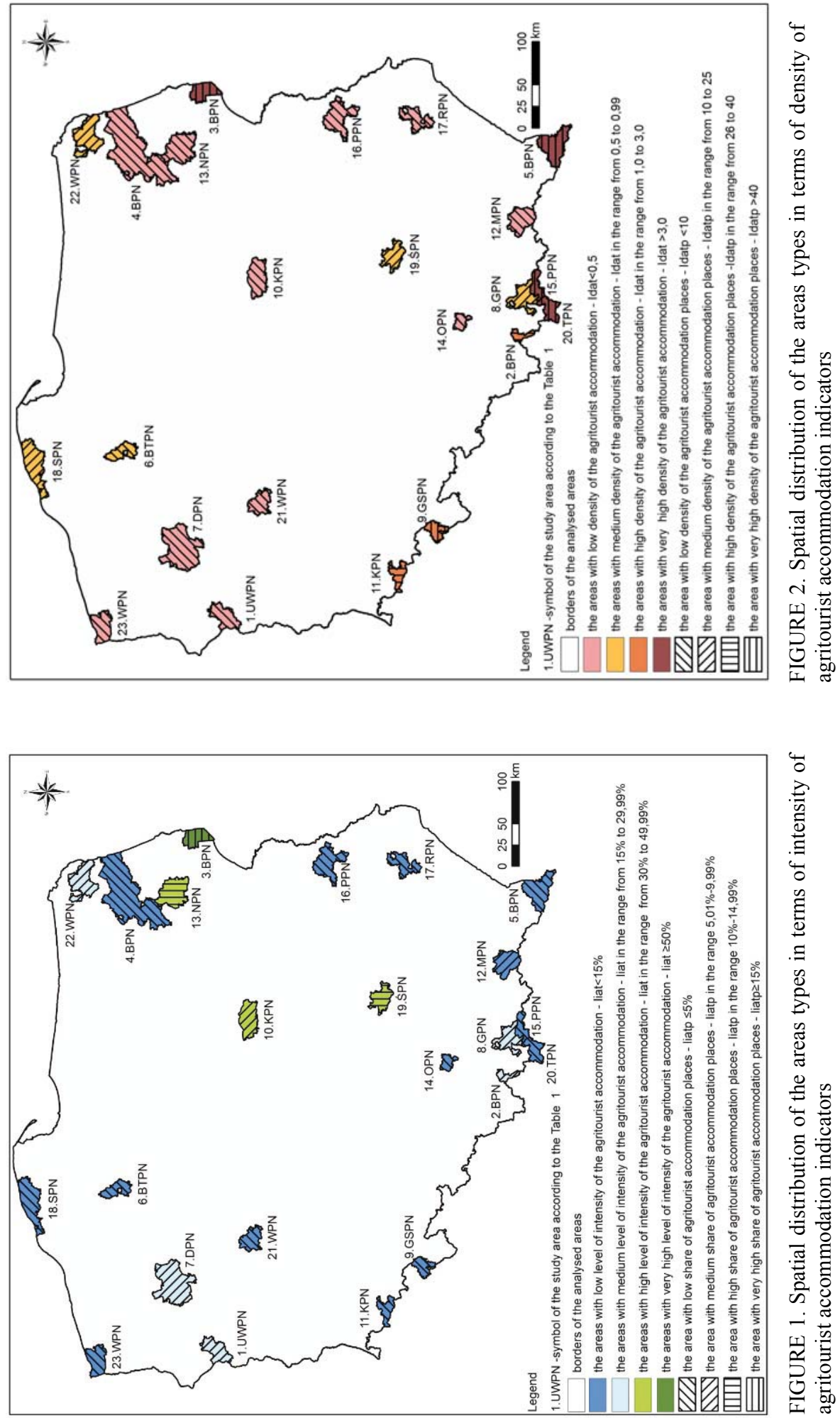


\section{CONCLUSIONS AND DISCUSSION}

Assessment of the selected issues concerning agritourism in areas located in the vicinity of national parks, indicates that:

- in the case of intensity of agritourist accommodation, there is prevalence of areas that have unsatisfactory state, both in terms of agritourist accommodation facilities and agritourist accommodation places; in the first case they constitute $60.9 \%$ (14 areas) and in the second $56.5 \%$ (13 areas) of the analysed set;

- the areas where the ratio of agrotourist accommodation to other forms of accommodation facilities is high or very high, amount to $17.4 \%$ (4) for the accommodation and $13 \%$ (3) for accommodation places;

- the medium level of intensity of agritourist accommodation concerns $21.7 \%$ (5) in case of the accommodation and $30.4 \%$ (7) in case of accommodation places;

- in the context of density of agritourist accommodation, Type I is predominant, which means poor use of existing farmsteads; such areas constitute $47.8 \%$ (11) in case of agritourist accommodation and $52.2 \%$ (12) in case of agritourist accommodation places;

- the areas where built-up agricultural land is used for creation of an agritourist accommodation in a high or very high rate is $30.4 \%$ (7), both in case of agritourist facilities and accommodation places;

- the average state in context of accommodation density is observed for $21.7 \%$ (5) of the studied area in terms of agritourist accommodation and $17.4 \%(4)$ areas in terms of accommodation places.

In the analysed areas there are 15.9 places (beds) per one accommodation facility. This is quite adequate to the housing stock resources available to farmers. It can be assumed that they offer up to five triple rooms, that provide additional income, which is not the subject of tax.

Considering spatial distribution of agritourist accommodation in the analysed areas it should be stated that it is uneven, with a decisive advantage of agritourism facilities in the mountain parks. The most pro-agritouristic areas around the national parks are these located near: Białowieża NP, Świętokrzyski NP, Kampinos NP. Whereas the least pro-agritouristic are the units located near: Biebrza NP, Bory Tucholskie NP, Magura NP, Ojców NP, Polesie NP, Roztocze NP, Wolin NP, Wielkopolska NP.

The special cases are the mountain parks, where agritourist accommodation does not constitute a large share of the total accommodation, but the use of farm buildings for tourist purposes is considerably high. It is the case in Tatra NP, Pieniny NP, Góry Stołowe NP, Karkonosze NP, Babia Góra NP. There are also several municipalities that stand out positively among other analyzed administrative units. This concerns in particular Zawoja in Babia Góra NP, Cisna and Lutowiska in Bieszczady NP, Radków in Góry Stołowe NP, Podgórzyn in Karkonosze NP, Łapsze Niżne, Czorsztyn, Krościenko nad Dunajcem in Pieniny NP, Bukowina Tatrzańska and Kościelisko in Tatra NP.

On the basis of more detailed analysis, it was concluded that the only munici- 
palities where agritourism is the dominant form of tourist accommodation are located in the Biebrza NP (Grajewo municipality), Kampinos NP (Kampinos, Leszno) and Wigry NP (Krasnopol).

Having analysed both the statistical data and the calculated indicators concerning intensity and density of the agritourist accommodation, it should be noted that unfortunately agritourism is not the predominant form of accommodation in the areas that have parts of national parks within their borders.

The data concerning the number of existing agritourist accommodation and presented analysis do not confirm the common opinion that since such areas are particularly designated to the development of agritourism they certainly do have a significant offer for agritourist accommodation (Sokół 2012, Ciepiela and Kur-Kowalska 2014). At the same time, the important role of this form of tourism has been partially confirmed in the mountain areas and disproved in case of the lake districts (Płazińska 2016). It can certainly be assumed that in some cases, letting rooms by farmers is not registered and the data provided by Central Statistical Office of Poland (GUS) may not be complete. Nevertheless, taking into account the non-taxation of such non-agricultural activities (renting up to 5 rooms) there is no reason to hide the agritourism.

\section{SUMMARY}

Combining the conservation of natural resources with touristic utilization of these resources, as well as enabling farmers to develop agritourism as an additional economic activity has its sci- entific dimension, but more importantly, it is also a significant issue for local communities.

The presented agritourism characteristics of areas located in the vicinity of Polish national parks could constitute some basis for discussion on the reasons for the low agritourism development in the areas with such high natural potential. In the document defining the spatial policy of communes, i.e. the study of conditions and directions of spatial development, in case of most analyzed administrative units, the existence of a national park is considered to be a strength of the area and its' development opportunity. However, the issue is complex. Not everywhere an attractive natural environment is sufficient to stimulate the activity of local agricultural communities. Other forms of accommodation (guest houses, hotels) prevail over agritourism. It raises a lot of controversy if that is the right way to go. The most striking example of tourism investment projects with no respect for the principles of nature and landscape protection was the construction of a huge hotel complex "Golębiewski" in Karpacz within the buffer zone of the Karkonosze Landscape Park. This investment is a classic evidence for the consumption of space for accommodation (Stankiewicz 2008).

\section{REFERENCES}

BASIŃSKI P., BUKOWSKA A., FERENC K., GOLIS A., GRUNT A., GRUNT M., KLAWINSKI M., KOŁTOWSKA M., KONATOWSKA M., KRÓL D., NOWAK M., PAWLAK A., SULANOWSKA N., ŚLIWA P. 2012: Agroturystyka w parkach krajobrazowych Wielkopolski [Agritourism in Wielkopolska, Landscape Parks of the Wielkopolska Region]. 
Zespół Parków Krajobrazowych Województwa Wielkopolskiego, Poznań, 1-64.

BEDNARCZYK-SZCZEPAŃSKA M., BAŃSKI J. 2014: Lokalizacyjne uwarunkowania oferty gospodarstw agroturystycznych w Polsce [Locational determinants of agritourism offer in Poland]. Pol. Geograph. Rev. 86 (2), 243-260.

BRELIKA. 2014: Społeczno-ekonomiczny aspekt rozwoju gospodarstw agroturystycznych a rola dóbr publicznych [Socio-economic aspect of agritourism farms development versus the role of public goods]. Rocz. SERiA 16 (3), 43-48.

CIEPIELA G.A., KUR-KOWALSKA M. 2014: Usługi agroturystyczne $\mathrm{w}$ gminach obejmujących tereny Białowieskiego Parku Narodowego i Biebrzańskiego Parku Narodowego [The agrotouristic services within municipalities of Białowieski National Park and Biebrzański National Park]. Zeszyty Naukowe Almamer Szkoła Wyższa 4 (73), 51-66.

CIESZEWSKA A. 2009: Ocena ruchu turystycznego w Kampinoskim Parku Narodowym w latach 2005-2006 [Assessment of tourism in Kampinos National Park in 2005-2006]. [In:] Trwałość i efektywność ochrony przyrody w polskich parkach narodowych [Sustainability and effectiveness of nature conservation in Polish national parks]. A. Andrzejewska, A. Lubański (Eds). Kampinos National Park, Izabelin, 99-112.

DRZEWIECKI M. 1992: Wiejska przestrzeń rekreacyjna [Rural recreation area]. Instytut Turystyki, Warszawa.

JALINIK M. 2009: Zarządzanie gospodarstwem ekoagroturystycznym na obszarach przyrodniczo cennych [Eco-agritouristic farm management on naturally valuable areas]. Ekon. Zarzadz. 14, 85-94.

JALINIK M. 2010: Uwarunkowania i czynniki rozwoju usług turystycznych na obszarach wiejskich [Conditions and development factors of tourist services in rural areas]. Probl. $\mathrm{Za}$ rzadz. 8, 3 (29), 119-137.

KOBYŁKA A., KULAWCZUK M. 2014: Formy turystyki i rekreacji na przykładzie polskich parków narodowych [Forms of tourism and recreation on the example of Polish national parks]. Zeszyty Naukowe Almamer Szkoła Wyzsza 4 (73), 87-104.

Ministerstwo Rolnictwa i Rozwoju Wsi, MRiRW 2017: RDP 2014-2020: Program Rozwoju Ob- szarów Wiejskich 2014-2020 [Rural Development Programme for 2014-2020]. Retrieved fromhttp://www.minrol.gov.pl/Wsparcie-rolnictwa/Program-Rozwoju-Obszarow-Wiejskich2014-2020.

MYGA-PIĄTEK U., JANKOWSKI G. 2009: Wpływ turystyki na środowisko przyrodnicze i krajobraz kulturowy - analiza wybranych przykładów obszarów górskich [Tourism impact on the natural environment and cultural landscape. Analysis of the selected examples for highlands]. Probl. Ekol. Kraj. 35, 27-38.

NOWAK E., KORAB I. 2012: Produkt turystyki wiejskiej i agroturystyki w Górach Świętokrzyskich [Rural tourism and agritourism product in the Świętokrzyskie Mountains]. Nierówności Spoteczne a Wzrost Gospodarczy 29, 220-232.

PŁAZIŃSKA K. 2016: Obszary przyrodniczo cenne czynnikiem wpływającym na rozmieszczenie gospodarstw agroturystycznych w Polsce [Valuable natural areas as one of the main factor affecting the arrangement of agritourism farms]. [In:] Turystyka wiejska. Zagadnienia przyrodnicze i kulturowe [Rural tourism - natural and cultural issues]. S. Graja-Zwolińska, A. Spychała, K. Kasprzak (Eds). Wieś Jutra, Poznań, 16-22.

PODAWCA K. 2004: Agroturystyka w parkach krajobrazowych - na przykładzie Gostynińsko-Włocławskiego Parku Krajobrazowego [Agrotourism in lanscape parks - an example of Gostynin-Włoclawek Landscape Park]. Towarzystwo Promocji Ziemi Gostynińskiej, Gostynin.

PODAWCA K. 2006: Planowanie przestrzenne gmin a zagospodarowanie przestrzenne parków narodowych [Spatial planning of municipalities in terms of spatial management of national parks]. Acta Sci. Pol. Architectura 5 (2), 97-110.

PODAWCA K., DĄBKOWSKI N. 2000: Punktowa metoda oceny zagród agroturystycznych [Scoring method of evaluation of agritourism farms]. [In:] Wieś polska w nowym stuleciu. Kierunki planowania przestrzennego i architektury współczesnej wsi [Polish village in the new century. Directions of spatial planning and architecture of contemporary villages]. Wydział Architektury Politechniki Białostockiej, Białystok - Wigry, 139-149. 
PRUKOP B., HERBERT J. 2014: Wykorzystanie potencjału Bieszczadzkiego Parku Narodowego w rozwoju agroturystyki na terenie Bieszczadów [Potential of using Bieszczady National Park of the development of agritourism in Bieszczady]. Zeszyty Naukowe Almamer Szkoła Wyższa 4 (73), 67-76.

PRZEZBÓRSKA-SKOBIERAJ L., SOBOTKA S. 2016: Propozycja delimitacji regionów agroturystycznych w Polsce [Proposal of delimitation of agritourism regions in Poland]. IRWiR PAN 2 (171), 173-197.

SIKORA J. 2012: Agroturystyka. Przedsiębiorczość na obszarach wiejskich [Agritourism - Entrepreneurship in rural areas]. Wydawnictwo C.H. Beck, Warszawa.

SOKÓŁ J.L. 2012: Działalność gospodarstw agroturystycznych na obszarze Narwiańskiego Parku Narodowego w ocenie turystów i ich nowe wyzwania [Tourists' assessment of the activities of agritourism farms in the Narew National Park and their challenges]. Econ. Manag. 3, 118-128.

STANKIEWICZ B. 2008: Percepcja w studiach krajobrazowych [Perception in landscape studies]. [In:] Studia krajobrazowe jako podstawa właściwego gospodarowania przestrzenią [Landscape studies as a basic of proper spatial management]. A. Zaręba, D. Chylińska (Eds). Uniwersytet Wrocławski, Instytut Geografii i Rozwoju Regionalnego, Wrocław, 67-77.

WIATRAK A.P. 1996: Wpływ agroturystyki na zagospodarowanie obszarów wiejskich [The influence of agritourism on the development of rural areas]. Zagad. Ekon. Roln. 1, 34-46.

ZIELIŃSKA A. 2006: Wykorzystanie wielowymiarowej analizy porównawczej dla obszarów przyrodniczo cennych według wskaźników ekorozwoju [Use of multidimensional comparative analysis for areas of natural value according to eco-development indicators]. [In:]
Regionalne studia ekologiczno-krajobrazowe Regional environmental and landscape studies. A. Richling, B. Stojek, M. Strzyż, I. Szumacher, A. Świercz A. (Eds). Probl. Ekol. Kraj. $16(2), 117-123$.

Streszczenie: Analiza wskaźników agroturystycznej bazy noclegowej na obszarach położonych w sasiedztwie parków narodowych. Coraz intensywniejszy rozwój turystyki powoduje, że staje się ona istotna w generowaniu wzrostu gospodarczego i zatrudnienia w krajach Unii Europejskiej. U podstaw funkcjonowania turystyki leży przygotowanie odpowiedniej bazy noclegowej. Wydaje się, że mało ,intensywne” i mało ,agresywne” formy zakwaterowania (nocleg) w istniejących lokalach i obiektach mieszkalnych są najbardziej właściwe na terenach o dużych wartościach przyrodniczych. W artykule przedstawiono badania dla 23 obszarów położonych $\mathrm{w}$ bezpośrednim sąsiedztwie parków narodowych. Na podstawie analizy wskaźnikowej badane tereny podzielono na 4 typy według intensywności agroturystyki w stosunku do innych form zakwaterowania oraz gęstości występowania bazy agroturystycznej. Otrzymane wyniki mogą świadczyć, że sąsiedztwo parku narodowego zdecydowanie nie jest czynnikiem determinującym podjęcie działalności agroturystycznej.

\section{MS received November 2017}

\section{Author's address:}

Konrad Podawca

Katedra Inżynierii Budowlanej

Wydział Budownictwa i Inżynierii Środowiska SGGW

ul. Nowoursynowska 166, 02-787 Warszawa

Poland

e-mail:konrad_podawca@sggw.pl 